\title{
Histopathological analysis of liver in Puntius ticto exposed to water soluble fraction (WSF) of petrol
}

\author{
Preeti Handa K akkar*, R. M. Saxena and M amta J oshi \\ Department of Zoology, D.A.V. (P.G.) College, Dehradun-248001 (Uttarakhand), INDIA \\ *Corresponding author. E-mail: preetisep3@gmail.com
}

Abstract: The fresh water fish P untius ticto were exposed to lethal concentration of water soluble fraction (WSF) of petrol (5\%-PF1, 10\%-PF2, 15\%-PF3, 20\%-PF4 and 25\%-PF5) for 96 hours. The exposure of WSF produced some conspicuous histopathological changes in liver. The swelling of hepatocytes, degeneration, necrosis, hemolysis, dilation, congestion and fibrosis in blood sinusoids were the prominent changes observed. The histological analysis showed increasing damages dose-dependents and time-dependents.

Keywords: Water soluble fraction, Petrol, Fish, Liver, Histopathology

\section{INTRODUCTION}

While the development of science and technology has improved and widened the course of man's life, it has also posed threats to his surroundings through varied pollutants. Pollution from industrial and petroleum- related activities are common in many parts of the world. Industrialization and urbanization are the main causes for such pollution (Furia, 2004).

Furthermore, ever increasing number of vehicles and stationary engines has lead to fast growth of automobile workshops in city areas. The washing and servicing of engines and vehicles generate a large volume of petroleum-based wastes. Petrol used as fuel for automobiles and solvents for grease, stains and paints. Petrol is a refined crude oil product of a mixture of noncyclic volatile hydrocarbons. The toxicity of Petroleum is mostly related to its water soluble fraction (WSF) that contains organic and inorganic compounds. WSF of petrol fuel present in water has adverse effect on the health of fishes and ultimately of human beings. Thus, the aim of this study was to assess the effect of WSF on fishes, because it is a good source of protein and vitamins.

\section{MATERIALS AND METHODS}

WSF was prepared as per the method given by Dede and Kaglo (2001). Different concentration of petrol fuel were denoted as PF1-5\%, PF2-10\%, PF3-15\%, PF $4-20 \%$ and PF5-25\%. Puntius ticto were collected from local rivers of Doon Valley and brought to the laboratory. After acclimatization the fishes were divided into 6 groups of about same size $(6-8.5 \mathrm{~cm})$ and weight $(15-20 \mathrm{gm})$. A group of ten fishes was put in six different troughs, 1 serving as control and other 5 as experimental to study the effect of
WSF on fishes. The fishes were exposed to various concentrations of WSF of petrol for 96 hours. The fish alive after 96 hours were carefully removed from the test solution and sacrified immediately. For histopathological examination the liver were fixed in Bouins fluid for 24 hours followed by dehydration, embedding, sectioning and staining adopting the standard methods (Gurr, 1956). Detailed histopathological studies of control and treatment sections (5 microns) were made under microscope and photographs were taken.

\section{RESULTS AND DISCUSSION}

Liver of control fish showed normal hepatic acini arrangement in regular manner. Hepatocytes have polygonal shape with clear cellular border lines and homogenous cytoplasm. The quite concentric nucleus has clear nucleoli. Comparing the sections of the control and experimental fishes it was observed that degeneration of endothelial lining cells at 2\%-PF1. The histopathological changes of the liver were more pronounced at $4 \%$-PF2, there was marked swelling of the hepatocytes in places with areas of diffuse necrosis. The normal architecture of liver tissue was markedly disrupted. Sinusoids in most cases were distended \& central vein appeared severely damaged due to marked swelling and degeneration of endothelial lining cells. With increasing the concentration hepatopancreas damage became more conspicuous and hemolysis of hepatic blood vessels was observed at $6 \%-\mathrm{PF} 3$ treatment. The condition became more critical at higher concentration causing dilation and congestion in blood sinusoids at $8 \%$-PF4. Moreover coagulative fibrosis and necrosis between the hepatocytes were observed at 10\%-PF5 (Figs. 1-6). 

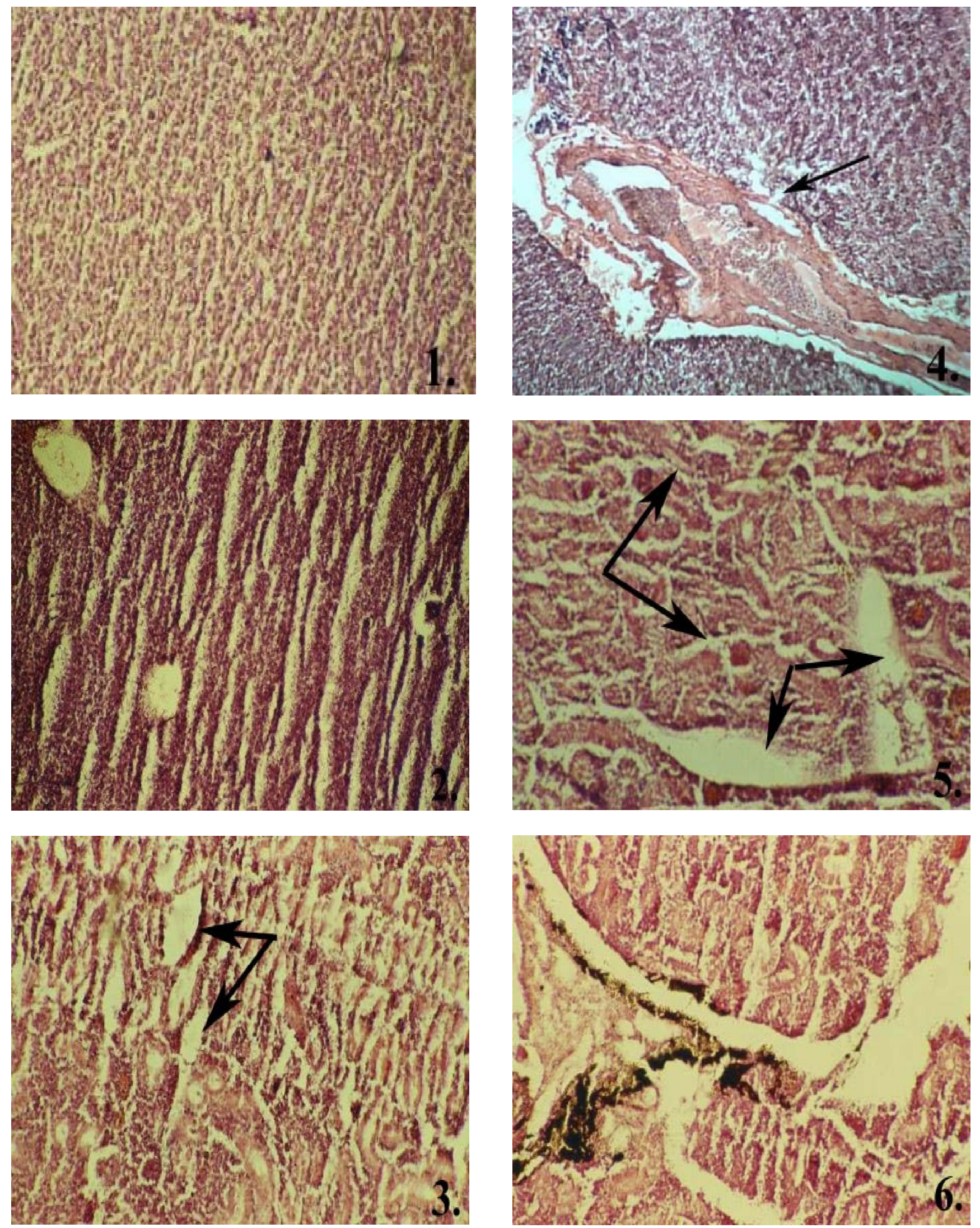

Figs. 1-6. 1. T.S liver-(control) Showing hepatocytes with their uniform nuclei and sinusuids. 2. (2\%-PF 1) showing degeneration of endothel ial lining cells 100X. 3. (4\%-PF2) Showing marked swelling of hepatocytes and diffuse necrosis100X. 4. (6\%-PF 3) Showing the hemolysis of hepatic blood vessels 100X. 5. (8\%-PF 4) Showing dilation and congestion in blood sinusoids 100X. 6. (10\%-PF 5) Showing coagulative fibrosis and necrosis $100 \mathrm{X}$. 
The organ most associated with the detoxification and biotransformation process is the liver, and due to its function, position and blood supply (Mohamed, 2009) it is also one of the organ most affected by WSF contamination in the water (Rodrigues and Fauta, 1998). Degeneration of endothelial cells and swelling of hepatocytes recorded in the liver of exposed fish may be suggestive of metabolic disorders and it is commonly associated with dietary deficiency in response to WSF. Similar result were observed by Solangi and Overstreet (1982) who reported degeneration of endothelial cells and swelling of hepatocytes in the liver of the fished M enidia beryllina and Trinectes maculates, exposed to WSF (50 $\mathrm{ppm}$ ) of crude oil. Necrosis of some portions of the liver tissue that were observed probably resulted from the excessive work required by the fish to get rid of the WSF from its body during the process of detoxification by the liver. The inability of fish to regenerate new liver cells may also have led to necrosis. The present results are in agreement with Akaishi et al. (2004) who reported similar changes in the liver of Astyanax sp. exposed to WSF of crude oil. Further Nabila et al. (2009) reported, petroleum carcinogenic compounds caused necrosis in hepatopancreatic cell of Palaemon serratus. Haemolysis may be due to the result of blood channel disruption and is indication of severe physical damage. The haemolysis, dilation, congestion \& fibrosis may be attributed to direct toxic effects of pollutants on hepatocytes, since the liver is the site of detoxification of all types of toxins and chemicals. These four alterations were not found earlier regarding with exposure of WSF of petrol fuel. The present result is in agreement with Mohamed (2009) who observed these alterations in Tilapia zillii and Solea vulgaris under the influence of different pollutants viz heavy metals, pesticides, fertilizers, salts and sewage from Lake Qarun, Egypt. These are entered to the lake with the drainage water. Here due to paucity of literature on the effect of WSF of petrol on fishes at some places other pollutants like crude oil, organophosphate dimetotato and diesel have been taken into consideration for discussion of present findings. Since the liver is usually the site of toxicant accumulation and detoxification, it is likely to show very extensive histopathology.

\section{Conclusion}

There is possibility that such histopatholological changes as observed in the experimental fish may be seen in human beings, which feed on such exposed fish, to be subjected to the same toxic effect. Therefore it is important that one should avoid any exposure to these samples and therapeutic use of these petroleum samples should highly be discouraged. The waste water should be treated before pouring in to the water bodies. Hence, Government should take remedial measures and pass appropriate legislation.

\section{ACKNOWLEDGEMENTS}

We are thankful to the principal D.A.V. (P.G.) College for providing necessary facilities. Thanks are also due to Dr. S.K. Gupta, Reader, D.B.S. (P.G.) College for suggestions.

\section{REFERENCES}

Akaishi, F.M., De Assis, H.C., Jakobi, S.C., Eras-stofella, D.R., St. jean, S.D., Courtenav, S.C., Lima, E.F., Wagener, A.L., Scofield, A.L., and Ribeiro, C.A., (2004). Morphological and neurotoxicological findings in tropical freshwater fish (Astyanax sp.) after waterborne and acute exposure to water soluble fraction (WSF) of crude oil. Arch E nviron. Contam. Toxical., 46 -2: 244-53.

Dede, E.B. and Kaglo, H.D.(2001). Aqua-toxicological effects of water soluble fractions (WSF) of Diesel fuel on 0 . niloticus fingerlings. J. Appl. Sci. Environ. M gt., 5-1: 93-96. .

Furia. Rosaria Rios (2004). Preliminary aspects of water soluble fraction of diesel oil effects on gill Histology of Trachinotus sp. International Congress on the biology of fish, 331-343

Gurr, E.(1956). Methods of analytical histology and histochemistry. Leonard Mill Books Ltd- London

Mohamed, Fatma, A.S. (2009). Histopathological studies on Tilapia Zillii and Solea Vulgaris from Lake Qarun, Egypt.World J ournal of $\mathrm{F}$ ish and $\mathrm{M}$ arine Sciences, $1: 29$ 39

Nabila, E., Abdelmeguid, Hassan, E. Awad Ahmed, M. Ibrahim and Nabiha A. Yousef, (2009). Ultrastructural changes in Hepatopancreuse of palemon Serratus, Following treatmant with Petroleum Carcinogenic. Compounds Pakistan J ournal of Nutrition, 8-6: 770-781.

Rodrigues, E. L. and E. Fanta. (1998). Liver histopathology of the fish B rachydanio rerio after acute exposure to sublethal levels of the organophosphate Dimetoato 500. Revista Brasileira D e Zoologia, 15: 441-450.

Solangi M.A. and Overstreet R.M. (1982) Histopathological changes in two etuarine fishes, M enidia beryllina (Cope) and Trinectes maculatus (Bloch and Schneider), exposed to crude oil and its water-soluble fractions. J ournal of Fish Diseases, 5: 13-35. 